\title{
Cochrane
}

Library

Cochrane Database of Systematic Reviews

\section{Domiciliary oxygen for chronic obstructive pulmonary disease} (Review)

Cranston JM, Crockett A, Moss J, Alpers JH

Cranston JM, Crockett A, Moss J, Alpers JH.

Domiciliary oxygen for chronic obstructive pulmonary disease.

Cochrane Database of Systematic Reviews 2005, Issue 4. Art. No.: CD001744.

DOI: 10.1002/14651858.CD001744.pub2.

www.cochranelibrary.com 
TABLE OF CONTENTS

HEADER 1

ABSTRACT

PLAIN LANGUAGE SUMMARY .....

BACKGROUND

OBJECTIVES

METHODS

RESULTS

Figure 1.

DISCUSSION

AUTHORS' CONCLUSIONS

ACKNOWLEDGEMENTS

REFERENCES

CHARACTERISTICS OF STUDIES

DATA AND ANALYSES

Analysis 1.1. Comparison 1 Continuous oxygen therapy versus nocturnal oxygen therapy, Outcome 1 Mortality.

Analysis 2.1. Comparison 2 Long-term oxygen therapy versus no oxygen therapy in severe hypoxaemia, Outcome 1 Mortality at 60 months.

Analysis 2.2. Comparison 2 Long-term oxygen therapy versus no oxygen therapy in severe hypoxaemia, Outcome 2 Change in weight.

Analysis 2.3. Comparison 2 Long-term oxygen therapy versus no oxygen therapy in severe hypoxaemia, Outcome 3 Change in FEV1.

Analysis 2.4. Comparison 2 Long-term oxygen therapy versus no oxygen therapy in severe hypoxaemia, Outcome 4 Change in FVC.

Analysis 2.5. Comparison 2 Long-term oxygen therapy versus no oxygen therapy in severe hypoxaemia, Outcome 5 Change in $\mathrm{PaO} 2$.

Analysis 2.6. Comparison 2 Long-term oxygen therapy versus no oxygen therapy in severe hypoxaemia, Outcome 6 Change in $\mathrm{PaCO} 2$.

Analysis 2.7. Comparison 2 Long-term oxygen therapy versus no oxygen therapy in severe hypoxaemia, Outcome 7 Change in packed cell volume.

Analysis 3.27. Comparison 3 Nocturnal oxygen therapy versus room air with mild to moderate hypoxaemia; change from baseline, Outcome 27 Mortality at 36 months for Fletcher and mortality for Chaouat (mean follow-up 35.6 months).

Analysis 4.1. Comparison 4 Long term oxygen therapy versus no oxygen therapy in mild to moderate hypoxaemia, Outcome 1 Mortality (maximum follow-up 85 months for the Gorecka study and 36 months for the Haidl study).

Analysis 4.2. Comparison 4 Long term oxygen therapy versus no oxygen therapy in mild to moderate hypoxaemia, Outcome 2 Mortality between oxygen $>15 \mathrm{hrs}$ per day and $<15 \mathrm{hrs}$ per day.

Analysis 4.3. Comparison 4 Long term oxygen therapy versus no oxygen therapy in mild to moderate hypoxaemia, Outcome 3 End exercise dyspnoea score.

Analysis 4.4. Comparison 4 Long term oxygen therapy versus no oxygen therapy in mild to moderate hypoxaemia, Outcome 4 Endurance time.

WHAT'S NEW

HISTORY

CONTRIBUTIONS OF AUTHORS

DECLARATIONS OF INTEREST

SOURCES OF SUPPORT

INDEX TERMS 
[Intervention Review]

\title{
Domiciliary oxygen for chronic obstructive pulmonary disease
}

\author{
Josephine M Cranston ${ }^{1}$, Alan Crockett ${ }^{2}$, John Moss ${ }^{3}$, John H Alpers4
}

1Discipline of General Practice, School of Population Health and Clinical Practice, Adelaide, Australia. 2Primary Care Respiratory Unit, Discipline of General Practice, The University of Adelaide, Adelaide, Australia. ${ }^{3}$ Department of Community Medicine, Public Health, Adelaide, Australia. ${ }^{4}$ Respiratory Unit, Flinders Medical Centre, Bedford Park, Australia

Contact address: Josephine M Cranston, Discipline of General Practice, School of Population Health and Clinical Practice, University of Adelaide, Adelaide, South Australia, 5005, Australia. josephine.cranston@adelaide.edu.au.

Editorial group: Cochrane Airways Group.

Publication status and date: Edited (no change to conclusions), published in Issue 4, 2008.

Citation: Cranston JM, Crockett A, Moss J, Alpers JH. Domiciliary oxygen for chronic obstructive pulmonary disease. Cochrane Database of Systematic Reviews 2005, Issue 4. Art. No.: CD001744. DOI: 10.1002/14651858.CD001744.pub2.

Copyright @ 2008 The Cochrane Collaboration. Published by John Wiley \& Sons, Ltd.

\section{A B S T R A C T}

\section{Background}

Domiciliary oxygen therapy has become one of the major forms of treatment for hypoxaemic chronic obstructive pulmonary disease (COPD) patients.

\section{Objectives}

To determine the effect of domiciliary oxygen therapy on survival and quality of life in patients with COPD.

\section{Search methods}

Randomised controlled trials (RCTs) were identified using the Cochrane Airways Group COPD register using the search terms: home OR domiciliary AND oxygen. Searches were current as of January 2007.

\section{Selection criteria}

Any RCT in patients with hypoxaemia and COPD that compared long term domiciliary or home oxygen therapy with a control treatment.

\section{Data collection and analysis}

Data extraction was performed independently by two reviewers.

\section{Main results}

Six randomised controlled trials were identified. Survival data were aggregated from two trials of the treatment of nocturnal oxygen therapy in patients with mild to moderate COPD and arterial desaturation at night. Survival data was also aggregated from two trials of continuous oxygen therapy versus no oxygen therapy in mild to moderate COPD. Data could not be aggregated for the other two trials because of differences in trial design and patient selection. Nott 1980: continuous oxygen therapy versus nocturnal oxygen therapy: there was a significant improvement in mortality after 24 months (Peto odds ratio $0.45,95 \%$ confidence interval 0.25 to 0.81 ). MRC 1981: domiciliary oxygen therapy versus no oxygen therapy: there was a significant improvement over five years in mortality in the group receiving oxygen therapy (Peto odds ratio $0.42,95 \%$ confidence interval 0.18 to 0.98 ). In the two studies of nocturnal oxygen versus no oxygen therapy in patients with COPD and arterial desaturation at night: there was no difference in mortality between treated and non treated groups for either trial or when the trials were aggregated. In the two trials of long-term oxygen therapy versus no oxygen therapy in COPD patients with mild to moderate hypoxaemia: there was no effect on survival for up to three years of follow up. 


\section{Authors' conclusions}

Long-term home oxygen therapy improved survival in a selected group of COPD patients with severe hypoxaemia $\left(\mathrm{arterial}^{\mathrm{PaO}} \mathrm{O}_{2}\right.$ less than $55 \mathrm{~mm} \mathrm{Hg}(8.0 \mathrm{kPa}))$. Home oxygen therapy did not appear to improve survival in patients with mild to moderate hypoxaemia or in those with only arterial desaturation at night.

\section{PLAIN LANGUAGE SUMMARY}

\section{Domiciliary oxygen for chronic obstructive pulmonary disease}

Some people with chronic lung disease (COPD - chronic bronchitis or emphysema) have low levels of oxygen in their blood. Oxygen levels might be low all the time, or only at night when breathing slows during sleep. Some people use bottled oxygen through the night at home, to try and improve their breathing. The review of trials found that when people with COPD and low levels of blood oxygen did this for the long term, their survival rates improved. However, it did not lengthen survival of people whose oxygen levels were only moderately low, or only low at night. 


\section{B A C K G R O U N D}

Patients with chronic lung disease develop chronic hypoxaemia which is related to the progression of their underlying condition. Over the last 20 years, domiciliary oxygen therapy has become one of the major forms of treatment for hypoxaemic chronic obstructive pulmonary disease (COPD) patients.

\section{O B JE C T IVES}

To determine the effect of domiciliary oxygen therapy on survival and quality of life in patients with COPD and hypoxaemia.

\section{METHODS}

\section{Criteria for considering studies for this review}

\section{Types of studies}

Any randomised controlled trial (RCT) in patients with hypoxaemia and COPD that compared long-term domiciliary or home oxygen therapy (LTOT) with a control group.

\section{Types of participants}

Adults with COPD, also known as Chronic Airflow Limitation (CAL), Chronic Obstructive Airways Disease (COAD) or Chronic Airflow Obstruction (CAO), who received home oxygen therapy in the community. The majority of the patients had chronic hypoxaemia, arterial oxygen tension $\left(\mathrm{PaO}_{2}\right)<55 \mathrm{~mm} \mathrm{Hg}(7.3 \mathrm{kPa})$, but some of the patients had $\mathrm{PaO}_{2}>55 \mathrm{~mm} \mathrm{Hg}$ at rest with evidence of nocturnal hypoxaemia or desaturation with exercise.

\section{Types of interventions}

The intervention in the active treatment group covered all forms of LTOT including provision of oxygen using cylinders, concentrators or liquid oxygen therapy. In the control group, the intervention was either placebo air by the same method of delivery or no specific intervention.

\section{Types of outcome measures}

(1) Survival

(2) Health related quality of life as measured by a validated instrument.

(3) Improvement in physiological parameters.

\section{Search methods for identification of studies}

\section{Electronic searches}

Trials were identified using the Cochrane Airways Group Specialised Register of trials, which is derived from systematic searches of bibliographic databases including the Cochrane Central Register of Controlled Trials (CENTRAL), MEDLINE, EMBASE and CINAHL, and hand-searching of respiratory journals and meeting abstracts. All records in the Specialised Register coded as 'COPD' were searched using the following terms:

((Oxygen* or O2 ) and (home* or domicil* or long-term or "long term")) or LTOT

\section{Searching other resources}

Following this, the bibliographies of each RCT were searched for additional papers that may have contained RCTs. Authors of identified RCTs were contacted but additional data was not available. In addition, companies who supply the oxygen delivery devices and members of the International Respiratory Care Club were contacted for unpublished studies.

\section{Data collection and analysis}

\section{Selection of studies}

All RCTs that appeared potentially relevant were assessed by three individuals, who then independently selected the trials for inclusion in this review. Disagreement was resolved by consensus.

\section{Data extraction and management}

Data for the trials were extracted by two reviewers ( $A B$ and JC). Authors were contacted in an attempt to obtain raw data from the trials.

\section{Assessment of risk of bias in included studies}

All trials to be included in the review were scored for allocation of concealment according to the following principles: Grade A: adequate concealment.

Grade B: unclear concealment.

Grade C: clearly inadequate concealment.

All trials were scored as double-blind, single-blind or not blinded/ not known. In addition, each study was assessed according to a 0-5 scale described by Jadad 1996, and summarised as follows:

1. Was the study described as randomised ( $1=y e s ; 0=$ no)?

2 . Was the study described as double-blind ( $1=$ yes; $0=$ no)?

3. Was there a description of withdrawals and dropouts (1=yes; $0=$ no)?

4. Was the method of randomisation well described and appropriate ( $1=$ yes; $0=$ no)?

5. Was the method of double-blinding well described and appropriate ( $1=$ yes; $0=$ no)?

6 . Deduct one point if methods for randomisation or blinding were inappropriate.

\section{Data synthesis}

For dichotomous variables, individual and pooled statistics were calculated as Peto Odds Ratios with 95\% Confidence Intervals (95\% $\mathrm{Cl})$. For continuous variables, individual statistics were calculated as Weighted Mean Differences (WMD) with $95 \% \mathrm{Cl}$.

The data was entered and the meta-analysis performed using RevMan Version 5 (Cochrane Review Manager, The Cochrane Collaboration).

\section{Subgroup analysis and investigation of heterogeneity}

Subgroup analysis included where possible:

1. A comparison of male with female patients.

2. Long-term continuous oxygen therapy versus nocturnal oxygen therapy.

3. Long-term oxygen therapy versus no oxygen therapy in patients with severe hypoxaemia.

4. Nocturnal oxygen therapy versus room air for arterial oxygen desaturation during sleep.

5. Long-term oxygen therapy versus no oxygen therapy for patients with mild to moderate hypoxaemia. 


\section{RESULT S}

\section{Description of studies}

\section{Results of the search}

Eight abstracts were identified from the comprehensive searches of the data bases. The full text was obtained for all of the abstracts. Three papers were found to be reports on various aspects of one RCT the NOTT study (NOTT 1980). One of these papers was excluded as it contained baseline data only (Grant 1982). The physiological data from another of these papers were combined with data from the original NOTT 1980 study report. Six RCTs were identified as being suitable for inclusion in this review.

\section{Included studies}

See Characteristics of included studies for a description of the following studies:

1. Continuous or nocturnal oxygen therapy in hypoxaemic chronic obstructive lung disease (NOTT 1980, Timms 1985).
2. Long-term domiciliary oxygen therapy in chronic hypoxic cor pulmonale complicating chronic bronchitis and emphysema (MRC 1981).

3. A double-blind trial of nocturnal supplemental oxygen for sleep desaturation in patients with COPD and a daytime $\mathrm{PaO}_{2}$ above 60 $\mathrm{mm} \mathrm{Hg}$ (Fletcher 1992).

4. Effect of long-term oxygen therapy on survival in patients with COPD with moderate hypoxaemia (Gorecka 1997).

5. A randomised trial of nocturnal oxygen therapy in COPD patients (Chaouat 1999).

6. Long-term oxygen therapy stops the natural decline of endurance in COPD patients with reversible hypercapnia (Haidl 2004).

\section{Risk of bias in included studies}

The concealment allocation was not commonly reported, although this was adequate in two studies. In one study even and odd numbers determined the treatment group assignment (Chaouat 1999; see Figure 1). However, the process of generating randomised schedules was satisfactory for four trials (NOTT 1980, MRC 1981, Gorecka 1997, Chaouat 1999) and unclear for two trials (Fletcher 1992, Haidl 2004).

Figure 1. Methodological quality summary: review authors' judgements about each methodological quality item for each included study.

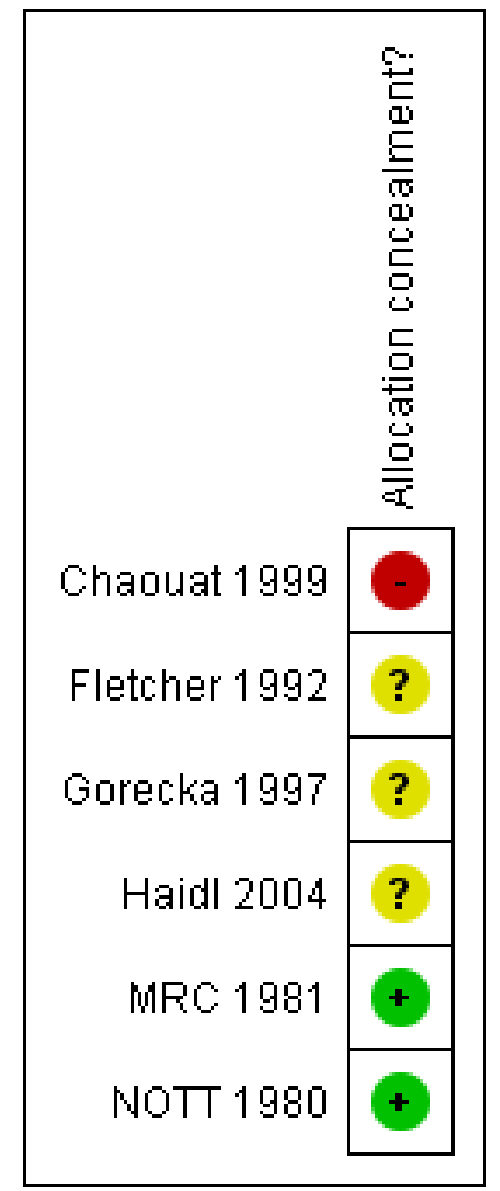

The methodological quality of the studies was scored as moderate (Jadad score 3) in five studies (NOTT 1980, MRC 1981, Fletcher
1992, Gorecka 1997, Chaouat 1999) and low (Jadad score 2) in the remaining trial (Haidl 2004). 


\section{Data analysis}

The data from the two studies of nocturnal oxygen for COPD patients with mild to moderate hypoxaemia (Fletcher 1992, Chaouat 1999) was aggregated. The data from the two studies of LTOT for COPD patients with mild to moderate hypoxaemia (Gorecka 1997, Haidl 2004) was also aggregated. None of the data from the other studies could be aggregated into a meta-analysis because of variation in treatment and types of patients recruited.

Two studies (Chaouat 1999, Haidl 2004) were analysed on an intention to treat basis due to some patients in the control groups deteriorating to the extent that they required LTOT during the follow-up period.

\section{Effects of interventions}

Continuous or nocturnal oxygen therapy in hypoxaemic chronic obstructive lung disease (NOTT 1980)

A total of 1,043 patients from six centres were screened for inclusion in the NOTT study. Eight hundred and nine patients were excluded for a variety of reasons including other major concomitant disease, refusal to participate, patients who had received previous oxygen therapy or patients with a $\mathrm{PaO}_{2}$ greater than $59 \mathrm{~mm} \mathrm{Hg}(7.9 \mathrm{kPa})$. The study was not blinded.

Two hundred and three patients with hypoxaemic chronic obstructive lung disease were randomly allocated to either nocturnal oxygen therapy $(n=102)$ or continuous oxygen therapy $(n=101)$ at an oxygen flow-rate of 1 to 4 litres per minute. The oxygen source was an oxygen concentrator, liquid oxygen or compressed gas. The mean age was 65.7 years in the nocturnal oxygen therapy group and 65.2 years in the continuous oxygen therapy group. Most patients were male, $80.4 \%$ in the nocturnal oxygen therapy group and $77.2 \%$ in the continuous oxygen therapy group.

After 12 months of oxygen therapy there was no difference in mortality between the treated and control groups of patients (Peto Odds Ratio: $0.53 ; 95 \% \mathrm{Cl} ; 0.25,1.11$ ). After 24 months of oxygen therapy, there was a significant improvement in mortality (Peto Odds Ratio: $0.45 ; 95 \% \mathrm{Cl}: 0.25,0.81$ ) for the continuous oxygen therapy group.

In this RCT, quality of life parameters and some physiological variables were studied, but the number of patients in each group was not defined and only baseline data was reported. However in the Timms's report of the NOTT 1980 study, rates of change of physiological variables were reported after six months of oxygen treatment. The authors reported nocturnal oxygen therapy was associated with significant decreases in mean pulmonary artery pressure and pulmonary vascular resistance during exercise. They also reported that continuous oxygen therapy was associated with larger decreases in resting and exercise pulmonary vascular resistance and significant improvements in the exercise response of mean pulmonary artery pressure and stroke index.

Weighted Mean Differences with $95 \% \mathrm{Cl}$ demonstrated no significant differences in the change from baseline, for continuous and nocturnal groups of patients, for the physiological parameters; right atrial pressure, pulmonary artery pressure, pulmonary wedge pressure, cardiac index, stroke volume index and pulmonary vascular resistance. However, the continuous oxygen therapy group demonstrated a significant increase in right ventricular stroke work index over the nocturnal group in response to exercise: (WMD: 6.20, $95 \% \mathrm{Cl} ; 0.52,11.88)$.

The study speculated that those patients most likely to benefit from continuous oxygen therapy would have relatively severely impaired quality of life and brain disfunction but relatively mild disturbances of pulmonary haemodynamics and exercise capacity.

Long-term domiciliary oxygen therapy in chronic hypoxic cor pulmonale complicating chronic bronchitis and emphysema (MRC 1981)

This controlled trial of LTOT took place in three centres in the United Kingdom. Eighty seven patients with a diagnosis of chronic bronchitis and emphysema, were randomised to receive oxygen therapy (treatment group) or no oxygen (controls). The study was not blinded. Patients were enrolled in the study if they had $\mathrm{PaO}_{2}$ of between 40 and $60 \mathrm{~mm} \mathrm{Hg}(5.3$ and $8 \mathrm{kPa}$ ) and one or more recorded episodes of heart failure with ankle oedema, and so were highly selected. The treatment group, 33 men and 9 women, received oxygen therapy for at least 15 hours a day at a flow-rate of a minimum of 2 litres per minute. Eight patients in the treatment group received liquid oxygen therapy and all but one of the patients (total number not disclosed) from one centre received oxygen via an oxygen concentrator. The remaining subjects received cylinder oxygen. A total of 33 men and 12 women were included in the control group.

Mean (range) age was 58.2 (44-69) years for the male treatment group, 56.2 (42-68) years for the male control group, 59.4 (55-67) years for the female treatment group and 59.3 (50-69) years for the female controls. Mean baseline $\mathrm{FEV}_{1}$ was 0.76 litres and 0.58 litres for the treatment male and female groups respectively and 0.65 litres and 0.63 litres for the control male and female groups. Mean baseline FVC was 1.92 litres and 1.31 litres for the treatment male and female groups respectively and 1.88 litres and 1.46 litres for the control male and female groups. Mean baseline $\mathrm{PaO}_{2}$ was $50.4 \mathrm{~mm}$ $\mathrm{Hg}(6.7 \mathrm{kPa})$ and $49.4 \mathrm{~mm} \mathrm{Hg}(6.6 \mathrm{kPa})$ for the treatment male and female groups respectively and $51.5 \mathrm{~mm} \mathrm{Hg}(6.9 \mathrm{kPa})$ and $51.8 \mathrm{~mm}$ $\mathrm{Hg}(6.9 \mathrm{kPa})$ for the control male and female groups.

There was an improvement in mortality over five years in the group receiving oxygen therapy (Peto Odds Ratio $0.42,95 \% \mathrm{Cl}: 0.18$ to 0.98 ). However, there was no difference in mortality for male patients in both treated and control groups up to 500 days from commencement of treatment. In female patients, mortality was improved for the oxygen-treated group from the commencement of treatment. However, the number of female patients in each of the treated and control groups was small ( $n=9$ and $n=12$ ).

Rates of change of physiological variables were reported for patients dying between 180 and 500 days and for those surviving over 500 days. Patient numbers in some subgroups were small $(\mathrm{n}<10)$ and only small changes were observed. Long-term survivors in the control group increased their $\mathrm{PaCO}_{2}$ to a greater extent than the oxygen therapy group (WMD: $-2.16,95 \% \mathrm{Cl} ;-4.04,-0.28$ ). The control group long-term survivors also had a greater rate of decline of $\mathrm{FEV}_{1}$ (WMD: $0.08,95 \% \mathrm{Cl} ; 0.04,0.12$ ) than the oxygen treated group. The study found that the male subjects most likely to benefit from oxygen therapy had a sum of the red cell mass and $\mathrm{PaCO}_{2}$ less than 98 . 
A double-blind trial of nocturnal supplemental oxygen for sleep desaturation in patients with COPD and a daytime $\mathrm{PaO}_{2}$ above $60 \mathbf{~ m m ~ H g}$. (Fletcher 1992)

Thirty eight patients with COPD and nocturnal sleep desaturation agreed to participate in this double-blind RCT. A further 13 patients with similar baseline pulmonary function who did not desaturate were also followed up but not randomised. The subjects were randomised to receive either nocturnal oxygen therapy $(n=19)$ or sham treatment $(n=19)$. In the control group, 6 patients died and there were 4 dropouts ( 2 withdrew, 1 developed daytime hypoxaemia, 1 was noncompliant). Of the original 19 treated subjects, 6 developed significant daytime hypoxaemia, 1 developed worsening of sleep apnea and there were 5 deaths.

Oxygen was supplied to the active treatment group by an oxygen concentrator. The control group received gas from an oxygen concentrator rendered ineffective. However, some control group patients received an oxygen concentration of $25 \%$ rather than the ambient concentration of $21 \%$, equivalent to an inspired oxygen tension of approximately $30 \mathrm{~mm} \mathrm{Hg} \mathrm{(4} \mathrm{kPa)} \mathrm{greater} \mathrm{than} \mathrm{if} \mathrm{they} \mathrm{had}$ received room air. Mean age in the control group was 61.2 years and mean age in the oxygen treated group was 62.1 years. The gender of the subjects was not given. The sham treated group and oxygen treated group used their concentrators for a mean of $9.4 \pm 0.9$ and $7.6 \pm 0.7$ hours per night, respectively .

Physiological variables were reported for the survivors at baseline and at 36 months. The authors found no significant effect of nocturnal oxygen therapy on any of the sleep parameters studied.

There was no difference in mortality after 36 months between the oxygen treated and sham treated groups. However, the possibility of a Type-2 error occurring could not be rejected due to the small study size although the point estimate of mortality was very close to the odds ratio of 1.0 .

\section{Effect of long-term oxygen therapy on survival in patients with COPD with moderate hypoxaemia (Gorecka 1997)}

One hundred and thirty five patients with COPD and moderate hypoxaemia referred to nine regional centres in Poland were included in this unblinded RCT. Patients with concomitant disease that might impact on survival were excluded from the study.

Sixty seven patients, 52 males 15 females, mean age 62.4 years formed the control group and 68 patients, 51 males 17 females, mean age 60.1 years, formed the treatment group. Both treated and control groups received "usual treatment" which consisted of bronchodilators, antibiotics, corticosteroids and diuretics as required. The oxygen group received oxygen from an oxygen concentrator at a flow-rate that raised resting $\mathrm{PaO}_{2}$ to greater than $65 \mathrm{~mm} \mathrm{Hg}(8.7 \mathrm{kPa})$. The patients were followed for three years or until death.

No difference in mortality during the study period was found between COPD patients with moderate hypoxaemia with conventional treatment plus LTOT versus conventional treatment only. In the intervention group, the duration of oxygen therapy (prescribed over 15 hours per day, used $13.5 \pm 4.4$ hours per day) did not affect survival.
Physiological parameters could not be assessed as they were not reported by treatment group.

\section{A randomised trial of nocturnal oxygen therapy in COPD patients (Chaouat 1999)}

Seventy six patients with COPD and mild to moderate daytime hypoxaemia exhibiting significant nocturnal desaturation were randomised into this unblinded study. The patients were recruited from six hospital outpatient clinics of four Europeans countries.

Thirty five patients, mean age $64 \pm 6$ years, gender not defined, formed the control group and 41 patients, mean age $63 \pm 8$ years the treatment group. Patients were excluded if they had a variety of co morbidities including left heart or congenital heart disease, interstitial lung disease, bronchiectasis, lung carcinoma or other severe disease that could influence survival. Patients with obstructive sleep apnea were also excluded. Patients in the treatment group were given concentrator oxygen for eight to ten hours per night at a flow rate usually of 2 litres per minute (mean use $8.9 \pm 1.9$ hours per day). The control group received no oxygen therapy. Data was analysed on an intention to treat basis due to some patients in both treatment and control groups requiring conventional LTOT of at least eighteen hours per day during the follow-up period.

There was no difference in mortality between the treated and control groups on an intention to treat basis.

Twelve patients in the nocturnal oxygen group and 10 control group patients deteriorated and required treatment with conventional LTOT during the follow-up period of from 2.5 to 60 months. Five of these patients subsequently died, two in the treated group and three in the control group. Nocturnal oxygen did not allow the prescription of LTOT to be delayed.

Rates of change of pulmonary haemodynamics parameters were not reported and so were not assessed in this meta-analysis. However, the authors reported no significant difference between treated and control groups in the evolution of any of these parameters over a two year period.

Long-term oxygen therapy stops the natural decline of endurance in COPD patients with reversible hypercapnia (Haidl 2004).

Twenty eight inpatients (26 males), aged 49-74 years, admitted to a German hospital with an acute exacerbation of COPD, mild hypoxaemia $\left(\mathrm{PaO}_{2} 66.5 \pm 6.3 \mathrm{~mm} \mathrm{Hg}\right)$ and moderate reversible hypercapnia during exercise were randomised to LTOT or to a control group. The control group received no oxygen therapy. The study was unblinded. Patients with malignant disease, left heart failure or other significant comorbidity were excluded from the study. Patients were followed up for three years.

The treatment group was prescribed oxygen therapy at a flow rate of 2 litres per minute for a minimum of 15 hours per day. However, patients used their concentrator a mean of $10.4 \pm 4.2$ hours per day.

A total of 14 patients were randomised to each study group. Physiological measurements were reported at baseline and at 1 year of follow-up. Mortality was reported after three years of followup. Mortality data was analysed on an intention to treat basis due to 
five patients in the control group requiring LTOT during the followup period.

The authors found a small but significant difference in endurance time between the LTOT and control groups after one year of treatment. Exercise endurance time was reported to be significantly reduced for the control group at one year but maintained for the treated group. Other physiological parameters $\mathrm{FEV}_{1}$, inspiratory vital capacity, $\mathrm{PaO}_{2}$ and residual volume/total lung capacity did not change with treatment. The authors also reported a significant increase in $\mathrm{PaCO}_{2}$ after one year of follow-up for the control group which was not observed in the treatment group.

End-exercise dyspnoea score was found to be significantly greater for the control group after one year of follow-up. Standard deviations of the mean change in measurements between baseline and one year were not reported and so mean change from baseline could not be assessed. After one year of treatment, the $95 \% \mathrm{Cl}$ for the WMD between treated and control groups for both dyspnoea and exercise endurance time overlapped the no-difference line (WMD (dyspnoea): -1.2, 95\% Cl; -2.47, 0.07, WMD (endurance time): $2.2,95 \% \mathrm{Cl} ;-0.73,5.13)$. However, the study was limited by the small number of patients randomised and wide standard deviations of the variables studied.

Four patients in the LTOT group and 3 in the control group died during the three year follow up period.

\section{Data aggregation in relation to mortality}

Aggregating the Chaouat 1999 and Fletcher 1992 studies, a weighting of $61.3 \%$ was applied to the Chaouat 1999 study and $38.7 \%$ to the Fletcher 1992 study. There was no difference in mortality between the treated and control groups. The pooled Peto Odds Ratio moved closer to unity, (pooled Peto Odds Ratio: 0.97, $95 \% \mathrm{Cl} ; 0.41,2.31$ ) than the individual Odds Ratios.

Aggregating the data for the two studies of LTOT versus no oxygen therapy for patients with mild to moderate hypoxaemia (Gorecka 1997, Haidl 2004), a weighting of $86.2 \%$ was applied to the Gorecka study and $13.8 \%$ to the Haidl study. There was no significant difference in mortality between the treated and control groups (pooled Peto Odds Ratio: 1.39, 95\% Cl; 0.74, 2.59).

\section{DISCUSSION}

Three studies (MRC 1981, Gorecka 1997, Haidl 2004) involved the treatment of subjects with COPD with LTOT compared with no oxygen therapy. However, the MRC 1981 study was not combined with the other two studies as subjects with severe hypoxaemia $\left(\mathrm{PaO}_{2}\right.$ 5.3-8.0 kPa, 40-60 mm Hg) were included in this study while the Gorecka 1997 and Haidl 2004 studies included subjects with mild to moderate hypoxaemia $\left(\mathrm{PaO}_{2} 56-65 \mathrm{~mm} \mathrm{Hg}\right.$ or $>55 \mathrm{~mm}$ $\mathrm{Hg}$ ). Although the three studies included a small number of female subjects, survival was only stratified by gender for the MRC 1981 study.

\section{Mortality}

Two of the six RCTs included in this meta-analysis demonstrated a significant survival advantage for the selected COPD subjects receiving LTOT. In the NOTT 1980 study there was a significant improvement in mortality for hypoxaemic COPD patients after 24 months of treatment with continuous LTOT over the nocturnal oxygen therapy group. In the MRC 1981 study LTOT produced a small but significant overall improvement in survival in both male and female patients with severe hypoxic cor pulmonale complicating chronic bronchitis and emphysema. However, the authors reported a different survival response between males and females. Survival for treated and control male patients was similar until 500 days from the commencement of treatment ("Survivor effect"). However, the mortality of the control female patients was reported to be significantly greater than that of the treated females from the commencement of home oxygen therapy.

A numbers needed to treat (NNT) estimate (1/absolute relative risk) of 4.5 can be calculated for the MRC 1981 study where the risk of death in the control group is 0.67 , the relative risk for the oxygen treated group is 0.45 , and the absolute risk reduction is 0.22 . Thus, for the MRC 1981 study, treating five patients with severe hypoxaemic COPD with long-term oxygen therapy saved one life over the five year study period.

We found no evidence to suggest that nocturnal supplemental oxygen for COPD patients with nocturnal sleep desaturation but mild to moderate daytime hypoxaemia improved mortality.

Long-term supplemental oxygen therapy for COPD patients with mild to moderate hypoxaemia (Gorecka 1997, Haidl 2004) did not prolong survival. However, in both of these studies, patients were using a mean of 13.5 hours or less per day of oxygen therapy.

The relatively small numbers of patients, the young age of participants and the lack of co morbidities in most of the above studies raises concerns about the applicability of the survival outcomes to current clinical situations. Patients with COPD fulfilling prescription guidelines for domiciliary home oxygen therapy appear to be older than the subjects included in these studies. The majority of these COPD patients have multiple co morbidities. The assumption that home oxygen therapy has a beneficial effect in these patients has not been demonstrated.

\section{Quality of life issues and physiological parameters}

The authors of the Haidl 2004 study reported that LTOT reduced exertional dyspnoea in COPD patients with mild to moderate hypoxaemia in association with an increase in endurance time. However, the number of patients included in the study was small, the standard deviations were wide and the weighted mean difference for both dyspnoea and endurance time included the nodifference line. Dyspnoea was not reported in the other controlled trials.

The MRC 1981 study reported that indicators such as general improvement in the sense of well-being, improved appetite, and general alertness were frequently found in those patients treated with oxygen therapy. However, no data was given. The NOTT 1980 study reported neuropsychological deficits in hypoxic COPD patients groups and observed small improvements in neuropsychologic function and quality of life when data from all patients was combined.

Other health outcome variables e.g. physiological parameters were analysed in the meta-analysis as mean change scores where these were reported, due to small differences in baseline mean values between treated and control groups. Any changes in 
physiological parameters in response to oxygen therapy were very small. However, all significant changes favoured the oxygen treated groups. The long-term survivors in the MRC 1981 study in the control group had a greater rise in $\mathrm{PaCO}_{2}$ than the oxygen treated group. Greater progression of hypercapnia was also reported for the control group in the Haidl 2004 study. However, this effect was not observed in the Fletcher 1992 or Chaouat 1999 studies.

Physiological variables should be considered intermediate outcomes of oxygen therapy treatment while survival and quality of life should be considered as the more definitive outcomes. It is possible that statistically significant improvement in some physiological variables had little measurable impact on the subjects' perceived quality of life or survival.

\section{Limitations of the studies}

This systematic review has highlighted several problems with the patient selection and study design. Only one of the studies was double-blinded due to the inability to blind liquid oxygen therapy. Thus all trials were included in this review. The treatment regime for the control groups of the studies varied from none for the MRC 1981, Gorecka 1997, Chaouat 1999 and Haidl 2004 trials, nocturnal oxygen therapy for the NOTT 1980 study to sham treatment through a disabled oxygen concentrator equivalent to $25 \%$ oxygen therapy in the Fletcher 1992 study. In the Fletcher 1992 study this level of oxygen therapy for the control subjects may have confounded the results as this higher oxygen tension may have been reflected in the $\mathrm{PaO}_{2}$ for this group.

The cross over during follow-up of patients in both the nocturnal oxygen and control groups in the Chaouat 1999 study and control group in the Haidl 2004 study may have influenced their survival.

In the NOTT 1980 study, the numbers of patients receiving the different modes of oxygen therapy treatment were not given. In the MRC 1981 study, there were some differences between treated and control groups at baseline. Females in the treated group appeared to have more compromised lung function than those of the control group while the reverse appeared to be apparent for the male patient groups. The mean number of hospitalisations and hospitalised days in the Fletcher 1992 study could not be included in this review as standard deviations were not given. The Gorecka
1997 study reported differences in studied variables by survivors and non survivors.

No data was reported in the two major studies (NOTT 1980 and MRC 1981) about the effects of continued or cessation of smoking or indeed if smoking status affected the outcomes. The mean $\mathrm{PaCO}_{2}$ tension at baseline was higher in the MRC 1981 study than in the NOTT 1980 study. This did not appear to influence the results. Other known prognostic indicators such as body mass index were not discussed in either of the studies. The lack of exacerbation data is also a further limiting factor in interpreting the results.

\section{AUTHORS' CONCLUSIONS}

\section{Implications for practice}

Long term oxygen therapy improved survival in a selected group of COPD patients with severe hypoxaemia. Long term oxygen therapy did not appear to improve survival in patients with COPD and moderate hypoxaemia nor in COPD patients with nocturnal desaturation but resting daytime oxygenation above that to qualify for oxygen therapy.

\section{Implications for research}

The role of long-term oxygen therapy in COPD with moderate hypoxaemia and or nocturnal desaturation requires further investigation with larger numbers of participants included in the studies.

Ethical concerns have been raised about the randomisation of patients to placebo and this may be a bar to obtaining more appropriate health status data about the effects of oxygen in more severely hypoxaemic subjects.

\section{ACKNOWLEDGEMENTS}

We wish to acknowledge the assistance provided by the Cochrane Airways Review Group staff (Steve Milan, Anna Bara and Jane Dennis) in identifying the trials from the register and obtaining copies of the papers, and the editorial support from Dr Peter Gibson, Australian Coordinator of the Cochrane Airways Group. Anna Bara provided extra support in teaching us the correct way to use RevMan and helping us with data extraction. 


\section{RE F E R E N CE S}

\section{References to studies included in this review}

Chaouat 1999 \{published data only\}

Chaouat A, Weitzenblum E, Kessler R, Charpentier C, Enrhart M, Schott $R$, et al. A randomized trial of nocturnal oxygen therapy in chronic obstructive pulmonary disease patients. European Respiratory Journal 1999;14(5):1002-1008. [MEDLINE: 10596681]

\section{Fletcher 1992 \{published data only\}}

Fletcher EC, Luckett RA, Goodnight-White SA, Miller CC, Qian W, Costarangos-Galarza C. A double-blind trial of nocturnal supplemental oxygen for sleep desaturation in patients with chronic obstructive pulmonary disease and a daytime $\mathrm{PaO} 2$ above $60 \mathrm{~mm} \mathrm{Hg}$. American Review of Respiratory Disease 1992;145(5):1070-6.

\section{Gorecka 1997 \{published data only\}}

Gorecka D, Gorzelak K, Sliwinski P, Tobiasz M, Zielinsli J. Effect of long-term oxygen therapy on survival in patients with chronic obstructive pulmonary disease with moderate hypoxaemia. Thorax 1997;52(8):674-9.

\section{Haidl 2004 \{published data only\}}

Haidl P, Clement C, Wiese C, Dellweg D, Kohler D. Long-term oxygen therapy stops the natural decline of endurance in COPD patients with reversible hypercapnia. Respiration 2004;71(4):342-7. [MEDLINE: 15316206]

\section{MRC 1981 \{published data only\}}

Report of the Medical Research Council Working Party. Longterm domiciliary oxygen therapy in chronic hypoxic cor pulmonale complicating chronic bronchitis and emphysema. Lancet 1981;1:681-5.

\section{CHARACTERISTICS OF STUDIES}

Characteristics of included studies [ordered by study ID]
NOTT 1980 \{published data only\}

Grant I, Heaton RK, McSweeny AJ, Adams KM, Timms RM. Neuropsychologic findings in hypoxemic chronic ostructive pulmonary disease. Archives of Internal Medicine 1982;142(8):1470-6.

* Nocturnal Oxygen Therapy Trial Group. Continuous or nocturnal oxygen therapy in hypoxemic chronic obstructive lung disease: a clinical trial. Annals of Internal Medicine 1980;93(3):391-8

Timms RM, Khaja FU, Williams GW. Hemodynamic response to oxygen therapy in chronic obstructive pulmonary disease. Annals of Internal Medicine 1985;102(1):29-36. [MEDLINE: 3966742]

\section{References to studies excluded from this review}

Grant 1982 \{published data only\}

Grant I, Heaton RK, McSweeny AJ, Adams KM, Timms RM. Neuropsychologic findings in hypoxemic chronic obstructive pulmonary disease. Archives of Internal Medicine 1982;142(8):1470-6.

\section{Additional references \\ Jadad 1996}

Jadad AR, Moore RA, Carroll D, Jenkinson C, Reynolds DJ, Gavaghan DJ, McQuay HJ. Assessing the quality of reports of randomized clinical trials: is blinding necessary?. Controlled Clinical Trials 1996;17(1):1-12. [MEDLINE: 8721797]

* Indicates the major publication for the study

\section{Chaouat 1999}

Methods Randomised, unblinded, controlled study. Randomisation by random sampling numbers; even numbers, oxygen therapy and odd numbers, no oxygen therapy, prospectively.

Participants 76 COPD patients were randomised, 41 to the nocturnal oxygen group and 35 to the control group. 46 patients ( 24 treated and 22 control patients) were available for haemodynamic monitoring at 2 years.

Interventions

Nocturnal oxygen therapy for 8-10 hours a night, at a flow to allow the nocturnal SaO2 to be constantly $>90 \%$.

Outcomes

Physiological parameters, Pulmonary haemodynamic parameters, Survival.

Notes

\section{Risk of bias}


Chaouat 1999 (Continued)

$\begin{array}{ll}\text { Allocation concealment? High risk } & \text { Randomisation by random sampling numbers; even numbers, oxygen therapy } \\ \text { and odd numbers, no oxygen therapy, prospectively. }\end{array}$
and odd numbers, no oxygen therapy, prospectively.

Fletcher 1992

Methods Randomised, double blind, controlled trial. Randomisation technique not described.

\begin{tabular}{ll}
\hline Participants & 38 COPD patients with nocturnal desaturation agreed to participate but the study was limited to 13 pa- \\
tients (9 patients, sham treated and 7 patients, oxygen treated) due to dropouts. Daytime PaO2 $>60$ \\
$\mathrm{~mm} \mathrm{Hg}$. Mean age 61.2 years in the sham treated group and 62.1 years in the oxygen treated group.
\end{tabular}

\begin{tabular}{ll}
\hline Interventions & Nocturnal oxygen or room air, 3 litres per min, supplied by a home concentrator. \\
\hline Outcomes & Mortality, Physiological parameters; FEV1, FVC, Pulmonary artery pressure. \\
\hline Notes & \\
\hline
\end{tabular}

\section{Risk of bias}

\begin{tabular}{lll}
\hline Bias & Authors' judgement & Support for judgement \\
\hline Allocation concealment? & Unclear risk & Information not available \\
\hline
\end{tabular}

Gorecka 1997

\begin{tabular}{|c|c|c|}
\hline Methods & \multicolumn{2}{|c|}{$\begin{array}{l}\text { Randomised, unblinded, controlled study. Randomisation schedules by computer generated random } \\
\text { numbers. }\end{array}$} \\
\hline Participants & \multicolumn{2}{|c|}{$\begin{array}{l}135 \text { patients with COPD and moderate hypoxaemia }(\mathrm{PaO} 2,56-65 \mathrm{~mm} \mathrm{Hg} \text { ) referred to nine regional cen- } \\
\text { tres in Poland. Age } 40-80 \text { years. }\end{array}$} \\
\hline Interventions & \multicolumn{2}{|c|}{$\begin{array}{l}\text { Conventional treatment consisted of bronchodilators, (theophylline, beta-2 agonists, and anticholiner- } \\
\text { gic drugs). Antibiotics, diuretics and corticosteroids were prescribed at the discretion of the physician. } \\
\text { Long term oxygen therapy was given at a flow rate adjusted to raise } \mathrm{PaO} 2 \text { above } 65 \mathrm{~mm} \mathrm{Hg} \text {. }\end{array}$} \\
\hline Outcomes & \multicolumn{2}{|l|}{ Mortality. } \\
\hline \multicolumn{3}{|l|}{ Notes } \\
\hline \multicolumn{3}{|l|}{ Risk of bias } \\
\hline Bias & Authors' judgement & Support for judgement \\
\hline Allocation concealment? & Unclear risk & $\begin{array}{l}\text { Randomisation schedules by computer generated random numbers. Conceal- } \\
\text { ment not reported. }\end{array}$ \\
\hline
\end{tabular}

\section{Haidl 2004}

$\begin{array}{ll}\text { Methods } & \begin{array}{l}\text { Randomised, unblinded controlled trial. Randomisation technique not described. The technician was } \\ \text { blinded as to randomisation schedule during baseline measurements. }\end{array}\end{array}$


Haidl 2004 (Continued)

Participants
28 patients ( 26 males and 2 females), 14 to control and 14 to treatment group. Age 49-74 years. COPD diagnosed by: (FEV1/FVC $<70 \%$ ).

$\mathrm{PaO} 2>55 \mathrm{~mm} \mathrm{Hg}$.

$\mathrm{PaCO} 2>45 \mathrm{~mm} \mathrm{Hg}$.

\begin{tabular}{ll} 
Interventions & $\begin{array}{l}\text { Long-term oxygen therapy at } 2 \text { litres per min for more than } 15 \text { hours per day. Control group; no oxygen } \\
\text { therapy. }\end{array}$ \\
\hline Outcomes & FEV1, inspiratory vital capacity, PaO2, PaCO2, RV/TLC, endurance time, end-exercise dyspnoea score af- \\
ter 1 year of treatment. Mortality at three years.
\end{tabular}

Notes

\section{Risk of bias}

\begin{tabular}{lll}
\hline Bias & Authors' judgement & Support for judgement \\
\hline Allocation concealment? & Unclear risk & Information not available \\
\hline
\end{tabular}

\section{MRC 1981}

\begin{tabular}{ll}
\hline Methods & Randomised controlled trial, (randomisation method: random numbers), parallel study. \\
\hline Participants & $\begin{array}{l}87 \text { patients ( } 66 \text { males : } 21 \text { females), age }<70 \text { years (range 42-69 years), FEV1 <1.2 litres, PaO2 between } 40 \\
\text { and } 60 \mathrm{~mm} \mathrm{Hg} \text { breathing air at rest, (two repeat measures } 3 \text { weeks apart). }\end{array}$ \\
\hline Interventions & Long-term domiciliary oxygen therapy versus no oxygen therapy. \\
\hline Outcomes & Mortality, FEV1, FVC, PaO2 and PaCO2. \\
\hline Notes &
\end{tabular}

\section{Risk of bias}

\begin{tabular}{lll}
\hline Bias & Authors' judgement & Support for judgement \\
\hline Allocation concealment? & Low risk & Random numbers; concealment of randomisation process not described. \\
\hline
\end{tabular}

\section{NOTT 1980}

\begin{tabular}{ll}
\hline Methods & Randomised controlled trial. Randomisation - computer generated. \\
\hline Participants & 203 patients; 101 received continuous oxygen therapy, $(77.2 \%$ males) and 102 received nocturnal oxy- \\
& gen therapy, ( $80.4 \%$ males). \\
& Entry criteria: \\
& clinical diagnosis of chronic obstructive lung disease, \\
& age $>35$ years. \\
& hypoxemia: PaO $2<=55 \mathrm{~mm} \mathrm{Hg}$ or PaO $2<=59$ plus one of the following; \\
& oedema, haematocrit $>=55 \%$, cor pulmonale on ECG: $3 \mathrm{~mm}$ in leads II, III, aVF \\
& Lung function: FEV1/FVC $<70 \%$ TLC $>=80 \%$ predicted.
\end{tabular}


NOTT 1980 (Continued)

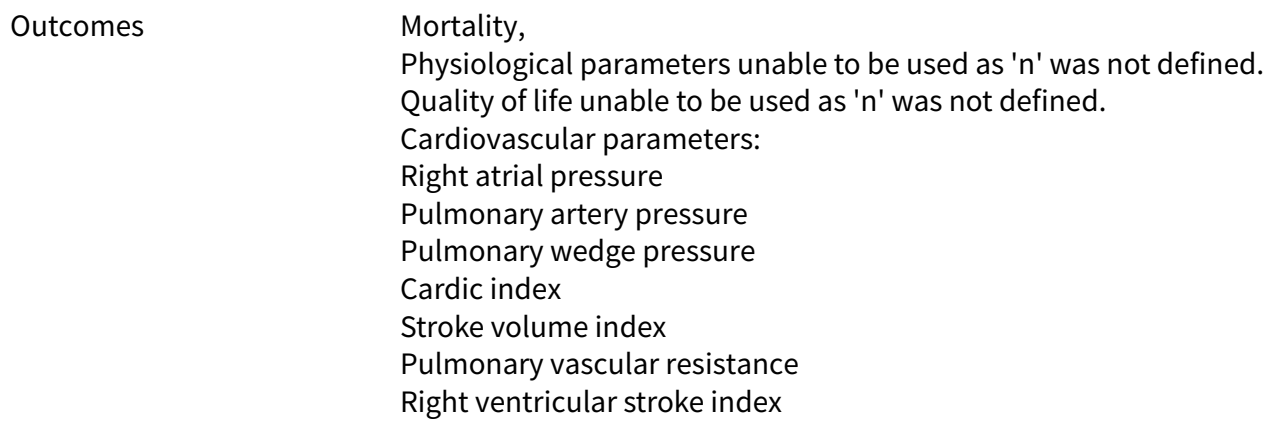

\section{Risk of bias}

\begin{tabular}{lll}
\hline Bias & Authors' judgement & Support for judgement \\
\hline Allocation concealment? & Low risk & $\begin{array}{l}\text { Randomisation: computer generated random numbers; concealment of ran- } \\
\text { domisation not described }\end{array}$ \\
\hline
\end{tabular}

Characteristics of excluded studies [ordered by study ID]

\begin{tabular}{ll}
\hline Study & Reason for exclusion \\
\hline Grant 1982 & Baseline data only from NOTT study patients. \\
\hline
\end{tabular}

\section{DATA AND ANALYSES}

Comparison 1. Continuous oxygen therapy versus nocturnal oxygen therapy

\begin{tabular}{|c|c|c|c|c|}
\hline $\begin{array}{l}\text { Outcome or sub- } \\
\text { group title }\end{array}$ & No. of studies & $\begin{array}{l}\text { No. of partici- } \\
\text { pants }\end{array}$ & Statistical method & Effect size \\
\hline 1 Mortality & 1 & & Peto Odds Ratio (Peto, Fixed, 95\% Cl) & Subtotals only \\
\hline 1.1 at 12 months & 1 & 203 & Peto Odds Ratio (Peto, Fixed, 95\% Cl) & $0.53[0.25,1.11]$ \\
\hline 1.2 at 24 months & 1 & 203 & Peto Odds Ratio (Peto, Fixed, 95\% Cl) & $0.45[0.25,0.81]$ \\
\hline $\begin{array}{l}2 \text { Change in right atrial } \\
\text { pressure }\end{array}$ & 0 & & Mean Difference (IV, Fixed, 95\% CI) & Subtotals only \\
\hline 2.1 Rest & 0 & 0 & Mean Difference (IV, Fixed, 95\% CI) & $0.0[0.0,0.0]$ \\
\hline 2.2 Legs up & 0 & 0 & Mean Difference (IV, Fixed, 95\% CI) & $0.0[0.0,0.0]$ \\
\hline 2.3 Exercise & 0 & 0 & Mean Difference (IV, Fixed, 95\% CI) & $0.0[0.0,0.0]$ \\
\hline
\end{tabular}




\begin{tabular}{|c|c|c|c|c|}
\hline $\begin{array}{l}\text { Outcome or sub- } \\
\text { group title }\end{array}$ & No. of studies & $\begin{array}{l}\text { No. of partici- } \\
\text { pants }\end{array}$ & Statistical method & Effect size \\
\hline $\begin{array}{l}3 \text { Change in pul- } \\
\text { monary artery pres- } \\
\text { sure }\end{array}$ & 0 & & Mean Difference (IV, Fixed, 95\% CI) & Subtotals only \\
\hline 3.1 Rest & 0 & 0 & Mean Difference (IV, Fixed, 95\% CI) & $0.0[0.0,0.0]$ \\
\hline 3.2 Legs up & 0 & 0 & Mean Difference (IV, Fixed, 95\% CI) & $0.0[0.0,0.0]$ \\
\hline 3.3 Exercise & 0 & 0 & Mean Difference (IV, Fixed, 95\% CI) & $0.0[0.0,0.0]$ \\
\hline $\begin{array}{l}4 \text { Change in pul- } \\
\text { monary wedge pres- } \\
\text { sure }\end{array}$ & 0 & & Mean Difference (IV, Fixed, 95\% CI) & Subtotals only \\
\hline 4.1 Rest & 0 & 0 & Mean Difference (IV, Fixed, 95\% CI) & $0.0[0.0,0.0]$ \\
\hline 4.2 Legs up & 0 & 0 & Mean Difference (IV, Fixed, 95\% CI) & $0.0[0.0,0.0]$ \\
\hline 4.3 Exercise & 0 & 0 & Mean Difference (IV, Fixed, 95\% CI) & $0.0[0.0,0.0]$ \\
\hline $\begin{array}{l}5 \text { Change in cardiac in- } \\
\text { dex }\end{array}$ & 0 & & Mean Difference (IV, Fixed, 95\% CI) & Subtotals only \\
\hline 5.1 Rest & 0 & 0 & Mean Difference (IV, Fixed, 95\% CI) & $0.0[0.0,0.0]$ \\
\hline 5.2 Exercise & 0 & 0 & Mean Difference (IV, Fixed, 95\% CI) & $0.0[0.0,0.0]$ \\
\hline $\begin{array}{l}6 \text { Change in stroke vol- } \\
\text { ume index }\end{array}$ & 0 & & Mean Difference (IV, Fixed, 95\% CI) & Subtotals only \\
\hline 6.1 Rest & 0 & 0 & Mean Difference (IV, Fixed, 95\% CI) & $0.0[0.0,0.0]$ \\
\hline 6.2 Exercise & 0 & 0 & Mean Difference (IV, Fixed, 95\% CI) & $0.0[0.0,0.0]$ \\
\hline $\begin{array}{l}7 \text { Change in pul- } \\
\text { monary vascular resis- } \\
\text { tance }\end{array}$ & 0 & & Mean Difference (IV, Fixed, 95\% CI) & Subtotals only \\
\hline 7.1 Rest & 0 & 0 & Mean Difference (IV, Fixed, 95\% CI) & $0.0[0.0,0.0]$ \\
\hline 7.2 Exercise & 0 & 0 & Mean Difference (IV, Fixed, 95\% CI) & $0.0[0.0,0.0]$ \\
\hline $\begin{array}{l}8 \text { Change in right ven- } \\
\text { tricular stroke work in- } \\
\text { dex }\end{array}$ & 0 & & Mean Difference (IV, Fixed, 95\% CI) & Subtotals only \\
\hline 8.1 Rest & 0 & 0 & Mean Difference (IV, Fixed, 95\% CI) & $0.0[0.0,0.0]$ \\
\hline 8.2 Exercise & 0 & 0 & Mean Difference (IV, Fixed, 95\% CI) & $0.0[0.0,0.0]$ \\
\hline
\end{tabular}


Analysis 1.1. Comparison 1 Continuous oxygen therapy versus nocturnal oxygen therapy, Outcome 1 Mortality.

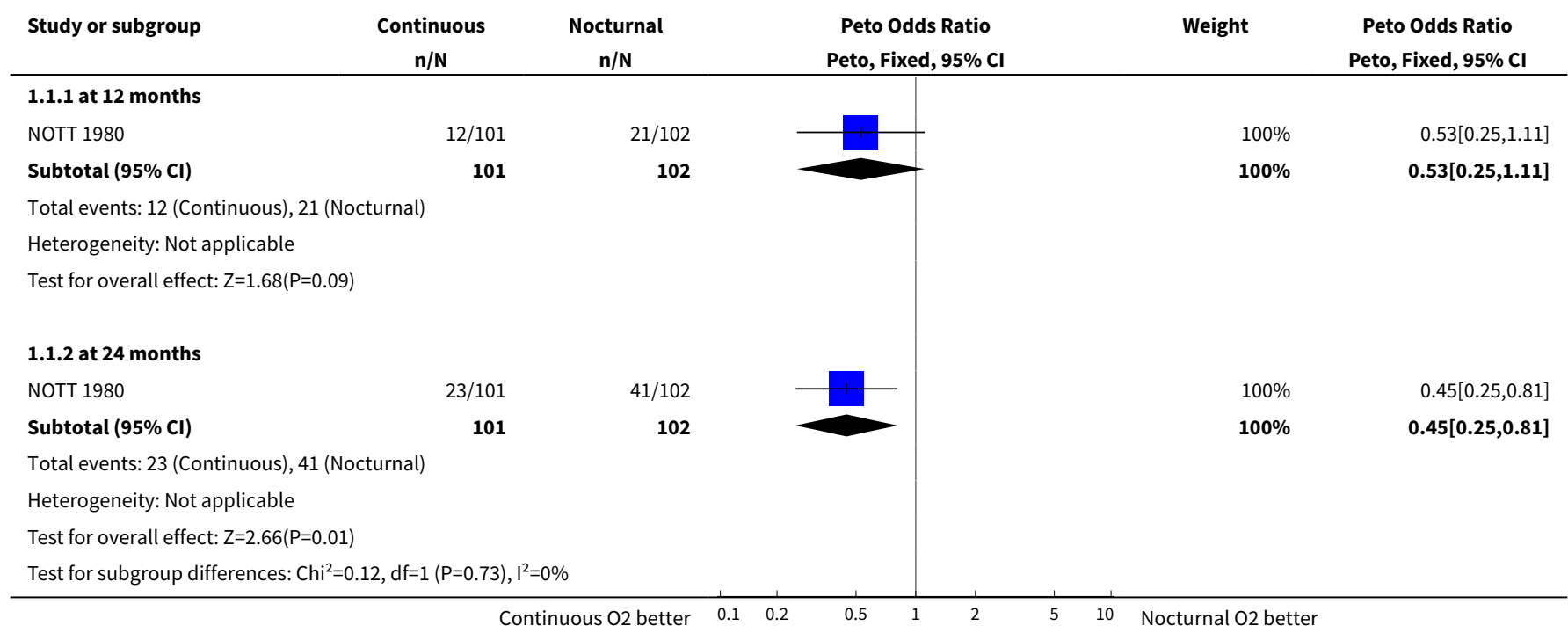

\section{Comparison 2. Long-term oxygen therapy versus no oxygen therapy in severe hypoxaemia}

\begin{tabular}{|c|c|c|c|c|}
\hline Outcome or subgroup title & No. of studies & $\begin{array}{l}\text { No. of partici- } \\
\text { pants }\end{array}$ & Statistical method & Effect size \\
\hline 1 Mortality at 60 months & 1 & 87 & $\begin{array}{l}\text { Peto Odds Ratio (Peto, Fixed, 95\% } \\
\mathrm{Cl} \text { ) }\end{array}$ & $0.42[0.18,0.98]$ \\
\hline 2 Change in weight & 1 & & Mean Difference (IV, Fixed, 95\% Cl) & Subtotals only \\
\hline $\begin{array}{l}\text { 2.1 Dying between } 180 \text { and } \\
500 \text { days }\end{array}$ & 1 & 22 & Mean Difference (IV, Fixed, 95\% CI) & $-3.36[-8.01,1.29]$ \\
\hline 2.2 Survivng over 500 days & 1 & 39 & Mean Difference (IV, Fixed, 95\% CI) & $1.08[-0.54,2.70]$ \\
\hline 3 Change in FEV1 & 1 & & Mean Difference (IV, Fixed, 95\% CI) & Subtotals only \\
\hline $\begin{array}{l}\text { 3.1 Dying between } 180 \text { and } \\
500 \text { days }\end{array}$ & 1 & 21 & Mean Difference (IV, Fixed, 95\% CI) & $-0.11[-0.27,0.05]$ \\
\hline 3.2 Surviving over 500 days & 1 & 40 & Mean Difference (IV, Fixed, 95\% Cl) & $0.08[0.04,0.12]$ \\
\hline 4 Change in FVC & 1 & & Mean Difference (IV, Fixed, 95\% Cl) & Subtotals only \\
\hline $\begin{array}{l}\text { 4.1 Dying between } 180 \text { and } \\
500 \text { days }\end{array}$ & 1 & 21 & Mean Difference (IV, Fixed, 95\% CI) & $0.56[0.12,1.00]$ \\
\hline 4.2 Survivng over 500 days & 1 & 40 & Mean Difference (IV, Fixed, 95\% CI) & $0.05[-0.89,0.99]$ \\
\hline 5 Change in $\mathrm{PaO} 2$ & 1 & & Mean Difference (IV, Fixed, 95\% Cl) & Subtotals only \\
\hline $\begin{array}{l}5.1 \text { Dying between } 180 \text { and } \\
500 \text { days }\end{array}$ & 1 & 19 & Mean Difference (IV, Fixed, 95\% CI) & $4.56[-1.04,10.16]$ \\
\hline
\end{tabular}




\begin{tabular}{|c|c|c|c|c|}
\hline Outcome or subgroup title & No. of studies & $\begin{array}{l}\text { No. of partici- } \\
\text { pants }\end{array}$ & Statistical method & Effect size \\
\hline 5.2 Surviving 500 days & 1 & 40 & Mean Difference (IV, Fixed, 95\% CI) & $1.07[-1.24,3.38]$ \\
\hline 6 Change in $\mathrm{PaCO} 2$ & 1 & & Mean Difference (IV, Fixed, 95\% CI) & Subtotals only \\
\hline $\begin{array}{l}\text { 6.1 Dying between } 180 \text { and } \\
500 \text { days }\end{array}$ & 1 & 19 & Mean Difference (IV, Fixed, 95\% CI) & $-0.96[-8.53,6.61]$ \\
\hline 6.2 Surviving over 500 days & 1 & 39 & Mean Difference (IV, Fixed, 95\% CI) & $-2.16[-4.04,-0.28]$ \\
\hline $\begin{array}{l}7 \text { Change in packed cell vol- } \\
\text { ume }\end{array}$ & 1 & & Mean Difference (IV, Fixed, 95\% CI) & Subtotals only \\
\hline $\begin{array}{l}7.1 \text { Dying between } 180 \text { and } \\
500 \text { days }\end{array}$ & 1 & 20 & Mean Difference (IV, Fixed, 95\% CI) & $1.32[-6.22,8.86]$ \\
\hline 7.2 Surviving over 500 days & 1 & 40 & Mean Difference (IV, Fixed, 95\% CI) & $-0.44[-1.52,0.64]$ \\
\hline
\end{tabular}

Analysis 2.1. Comparison 2 Long-term oxygen therapy versus no oxygen therapy in severe hypoxaemia, Outcome 1 Mortality at 60 months.

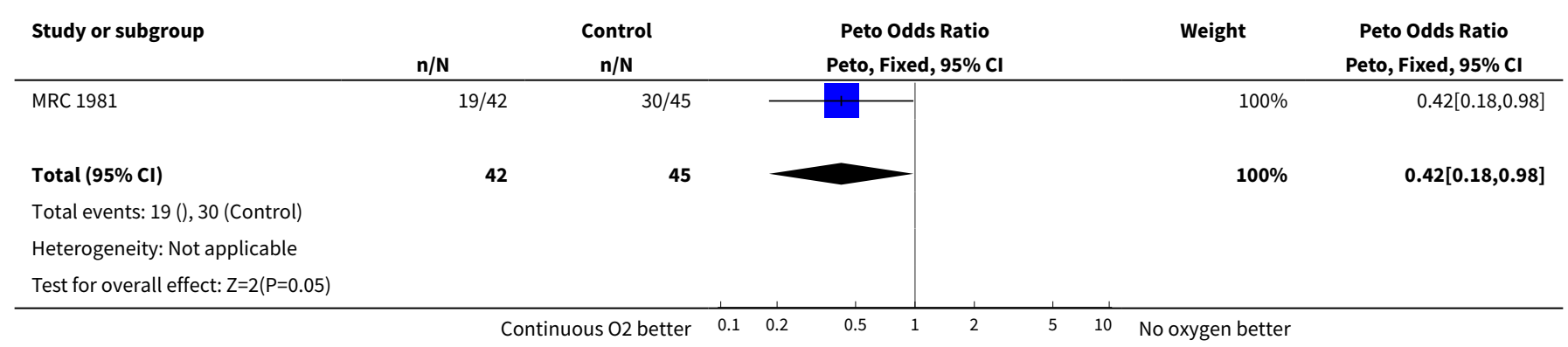

Analysis 2.2. Comparison 2 Long-term oxygen therapy versus no oxygen therapy in severe hypoxaemia, Outcome 2 Change in weight.

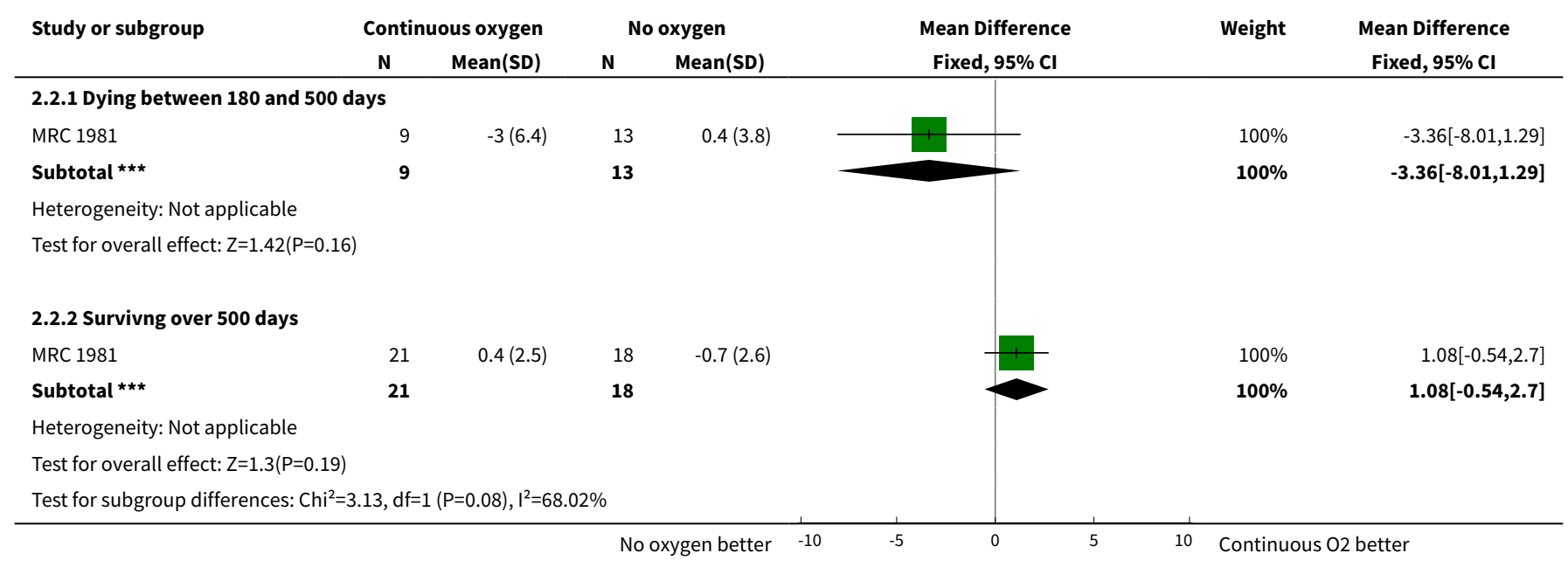


Analysis 2.3. Comparison 2 Long-term oxygen therapy versus no oxygen therapy in severe hypoxaemia, Outcome 3 Change in FEV1.

\begin{tabular}{|c|c|c|c|c|c|c|c|c|}
\hline \multirow[t]{2}{*}{ Study or subgroup } & \multicolumn{2}{|c|}{ Continuous oxygen } & \multicolumn{2}{|c|}{ No oxygen } & \multirow{2}{*}{\multicolumn{2}{|c|}{$\begin{array}{c}\text { Mean Difference } \\
\text { Fixed, } 95 \% \mathrm{Cl}\end{array}$}} & \multirow[t]{2}{*}{ Weight } & \multirow{2}{*}{$\begin{array}{c}\text { Mean Difference } \\
\text { Fixed, } 95 \% \mathrm{Cl}\end{array}$} \\
\hline & $\mathbf{N}$ & $\operatorname{Mean}(\mathrm{SD})$ & $\mathbf{N}$ & $\operatorname{Mean}(S D)$ & & & & \\
\hline \multicolumn{9}{|c|}{ 2.3.1 Dying between 180 and 500 days } \\
\hline MRC 1981 & 9 & $-0.1(0.2)$ & 12 & $-0(0.1)$ & & 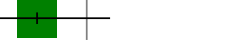 & $100 \%$ & $-0.11[-0.27,0.05]$ \\
\hline Subtotal $* \star \star$ & 9 & & 12 & & & & $100 \%$ & $-0.11[-0.27,0.05]$ \\
\hline \multicolumn{9}{|c|}{ Heterogeneity: Not applicable } \\
\hline \multicolumn{9}{|c|}{ Test for overall effect: $Z=1.33(P=0.18)$} \\
\hline \multicolumn{9}{|c|}{ 2.3.2 Surviving over 500 days } \\
\hline MRC 1981 & 22 & $0(0.1)$ & 18 & $-0(0.1)$ & & & $100 \%$ & $0.08[0.04,0.12]$ \\
\hline Subtotal ${ }^{\star \star \star}$ & 22 & & 18 & & & & $100 \%$ & $0.08[0.04,0.12]$ \\
\hline \multicolumn{9}{|c|}{ Heterogeneity: Not applicable } \\
\hline \multicolumn{9}{|c|}{ Test for overall effect: $Z=3.69(P=0)$} \\
\hline \multicolumn{9}{|c|}{ Test for subgroup differences: $\mathrm{Chi}^{2}=4.96, \mathrm{df}=1(\mathrm{P}=0.03), \mathrm{I}^{2}=79.84 \%$} \\
\hline
\end{tabular}

Analysis 2.4. Comparison 2 Long-term oxygen therapy versus no
oxygen therapy in severe hypoxaemia, Outcome 4 Change in FVC.

\begin{tabular}{|c|c|c|c|c|c|c|c|}
\hline \multirow[t]{2}{*}{ Study or subgroup } & \multicolumn{2}{|c|}{ Continuous oxygen } & \multicolumn{2}{|c|}{ No oxygen } & \multirow{2}{*}{$\begin{array}{c}\text { Mean Difference } \\
\text { Fixed, } 95 \% \mathrm{Cl}\end{array}$} & \multirow[t]{2}{*}{ Weight } & \multirow{2}{*}{$\begin{array}{c}\text { Mean Difference } \\
\text { Fixed, } 95 \% \mathrm{Cl}\end{array}$} \\
\hline & $\mathbf{N}$ & Mean(SD) & $\mathbf{N}$ & $\operatorname{Mean}(\mathrm{SD})$ & & & \\
\hline \multicolumn{8}{|c|}{ 2.4.1 Dying between 180 and 500 days } \\
\hline MRC 1981 & 9 & $0.5(0.6)$ & 12 & $-0.1(0.4)$ & & $100 \%$ & $0.56[0.12,1]$ \\
\hline Subtotal ${ }^{\star \star \star}$ & 9 & & 12 & & & $100 \%$ & $0.56[0.12,1]$ \\
\hline \multicolumn{8}{|c|}{ Heterogeneity: Not applicable } \\
\hline \multicolumn{8}{|c|}{ Test for overall effect: $Z=2.5(P=0.01)$} \\
\hline \multicolumn{8}{|c|}{ 2.4.2 Survivng over 500 days } \\
\hline MRC 1981 & 22 & $-0(0.1)$ & 18 & $-0.1(2)$ & & $100 \%$ & $0.05[-0.89,0.99]$ \\
\hline Subtotal ${ }^{\star \star \star}$ & 22 & & 18 & & & $100 \%$ & $0.05[-0.89,0.99]$ \\
\hline \multicolumn{8}{|c|}{ Heterogeneity: Not applicable } \\
\hline \multicolumn{8}{|c|}{ Test for overall effect: $Z=0.1(P=0.92)$} \\
\hline \multicolumn{8}{|c|}{ Test for subgroup differences: $\mathrm{Chi}^{2}=0.92, \mathrm{df}=1(\mathrm{P}=0.34), \mathrm{I}^{2}=0 \%$} \\
\hline
\end{tabular}

Analysis 2.5. Comparison 2 Long-term oxygen therapy versus no oxygen therapy in severe hypoxaemia, Outcome 5 Change in $\mathrm{PaO} 2$.

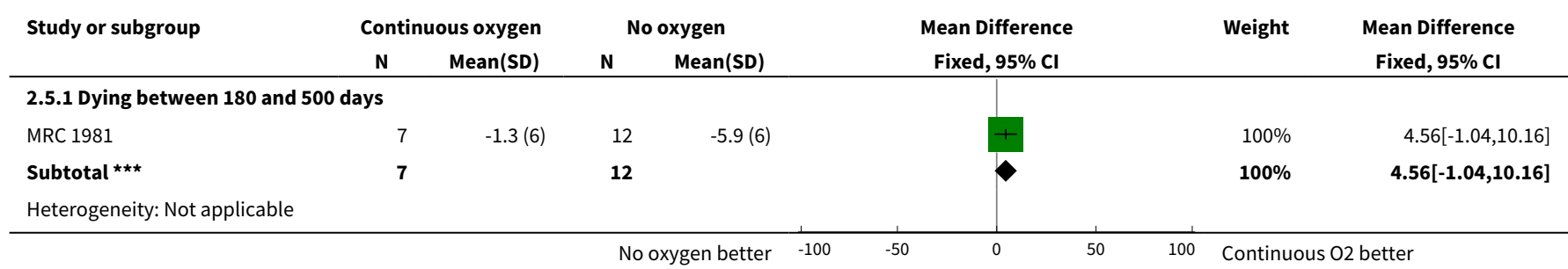




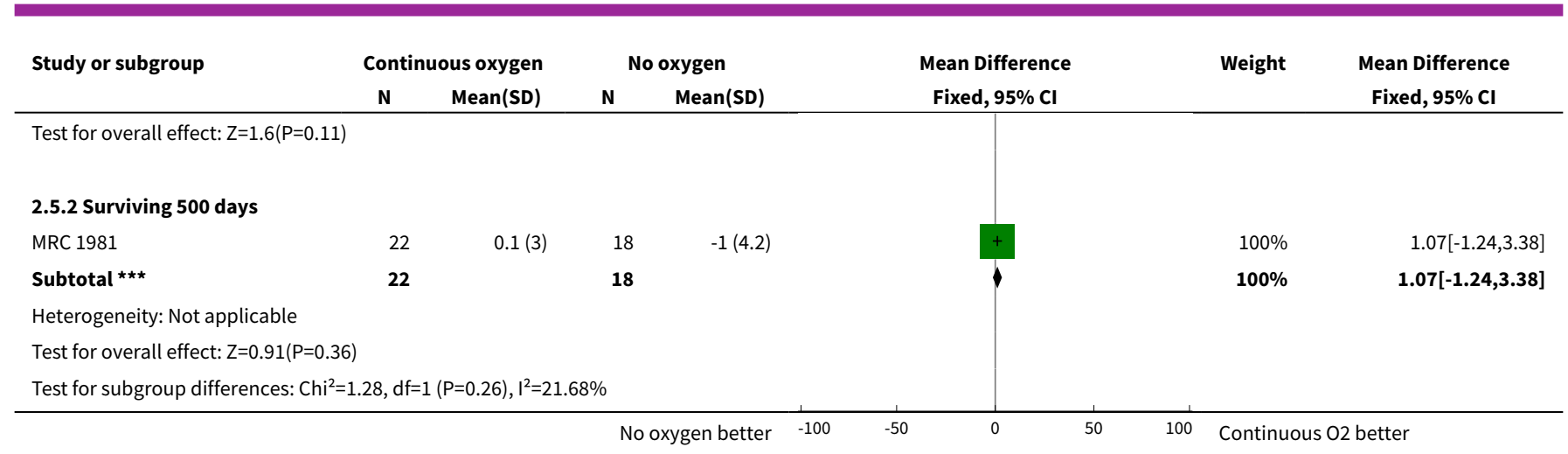

Analysis 2.6. Comparison 2 Long-term oxygen therapy versus no oxygen therapy in severe hypoxaemia, Outcome 6 Change in PaCO2.

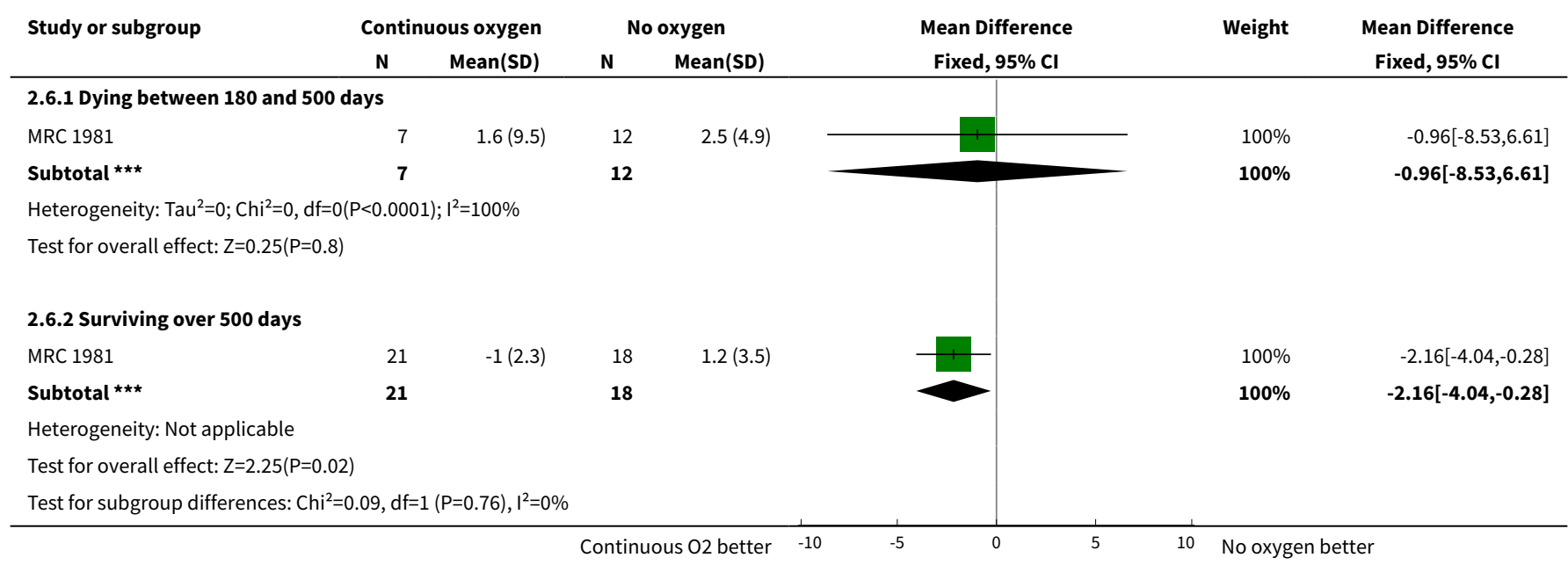

Analysis 2.7. Comparison 2 Long-term oxygen therapy versus no oxygen therapy in severe hypoxaemia, Outcome 7 Change in packed cell volume.

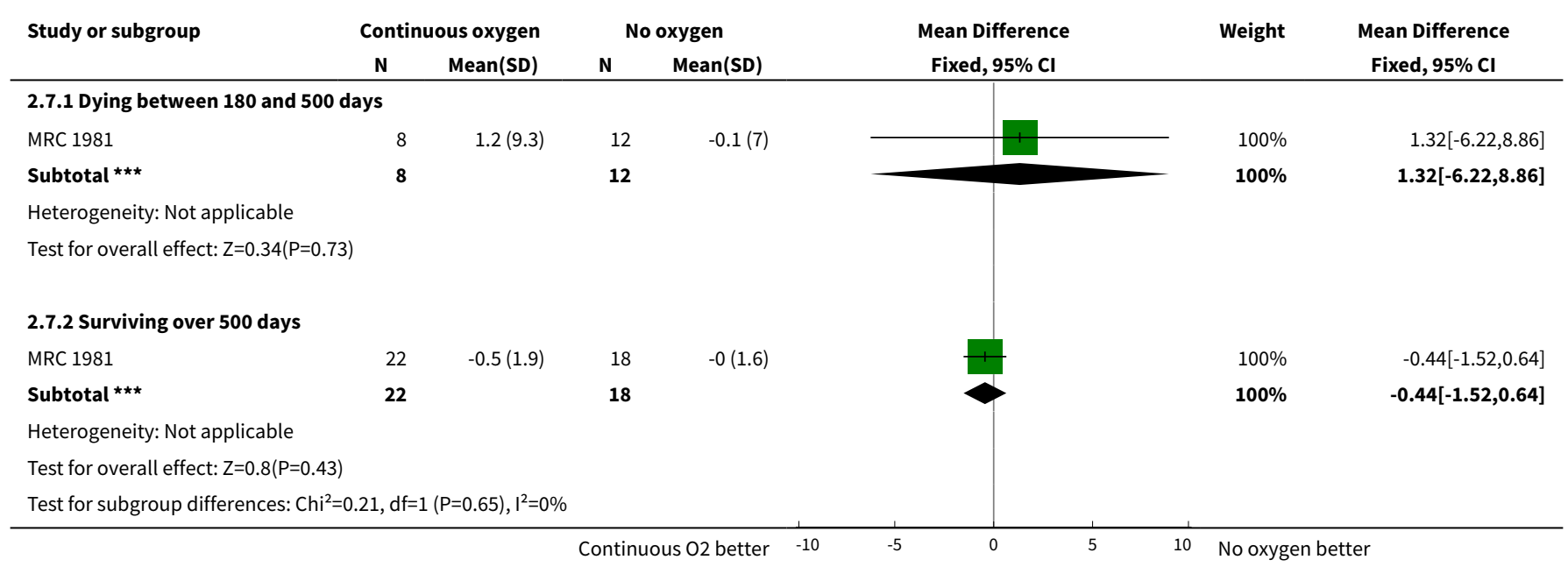


Comparison 3. Nocturnal oxygen therapy versus room air with mild to moderate hypoxaemia; change from baseline

\begin{tabular}{lllll}
\hline Outcome or subgroup title & No. of studies & $\begin{array}{l}\text { No. of partici- } \\
\text { pants }\end{array}$ & Statistical method & Effect size \\
\hline $\begin{array}{l}27 \text { Mortality at } 36 \text { months for Fletcher and } \\
\text { mortality for Chaouat (mean follow-up 35.6 } \\
\text { months) }\end{array}$ & 2 & 114 & $\begin{array}{l}\text { Peto Odds Ratio (Peto, } \\
\text { Fixed, 95\% Cl) }\end{array}$ & \\
\hline
\end{tabular}

Analysis 3.27. Comparison 3 Nocturnal oxygen therapy versus room air with mild to moderate hypoxaemia; change from baseline, Outcome 27 Mortality at 36 months for Fletcher and mortality for Chaouat (mean follow-up 35.6 months).

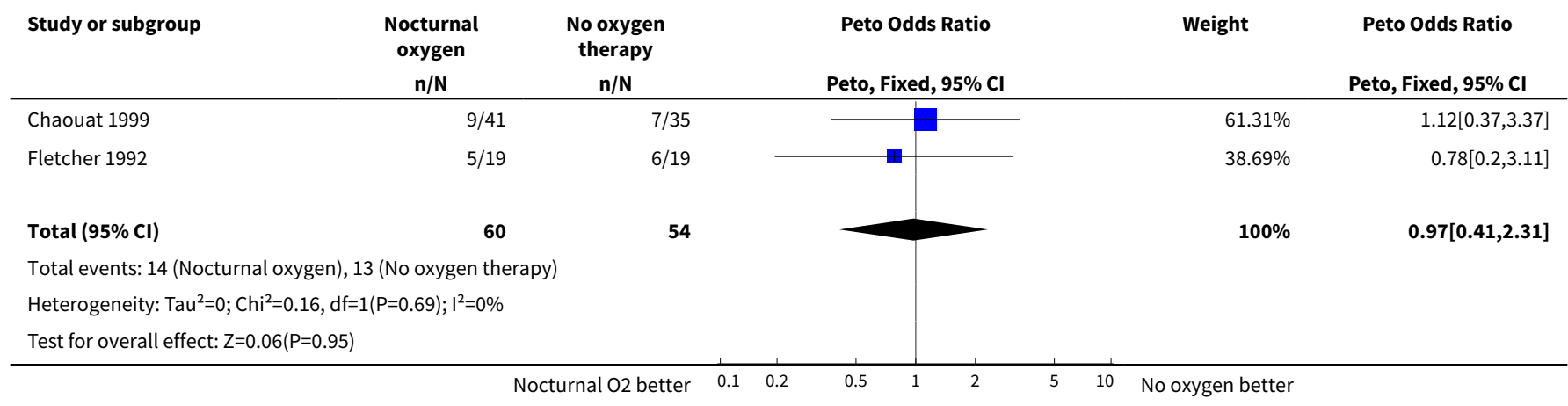

Comparison 4. Long term oxygen therapy versus no oxygen therapy in mild to moderate hypoxaemia

\begin{tabular}{lllll}
\hline Outcome or subgroup title & No. of studies & $\begin{array}{l}\text { No. of partici- } \\
\text { pants }\end{array}$ & Statistical method & Effect size \\
\hline $\begin{array}{l}1 \text { Mortality (maximum follow-up } 85 \\
\text { months for the Gorecka study and 36 } \\
\text { months for the Haidl study) }\end{array}$ & 2 & 163 & $\begin{array}{l}\text { Peto Odds Ratio (Peto, } \\
\text { Fixed, 95\% Cl) }\end{array}$ & 1.39 [0.74, 2.59] \\
\hline $\begin{array}{l}\text { 2 Mortality between oxygen }>15 \text { hrs per } \\
\text { day and <15hrs per day }\end{array}$ & 1 & 68 & Peto Odds Ratio (Peto, & 1.67 [0.62, 4.47] \\
\hline 3 End exercise dyspnoea score & 1 & 28 & Mean Difference (IV, Fixed, & -1.20 [-2.47, 0.07] \\
\hline 4 Endurance time & 1 & 28 & $95 \%$ Cl) & $\begin{array}{l}\text { Mean Difference (IV, Fixed, } \\
95 \% \text { Cl) }\end{array}$ \\
\hline
\end{tabular}


Analysis 4.1. Comparison 4 Long term oxygen therapy versus no oxygen therapy in mild to moderate hypoxaemia, Outcome 1 Mortality (maximum follow-up 85 months for the Gorecka study and 36 months for the Haidl study).

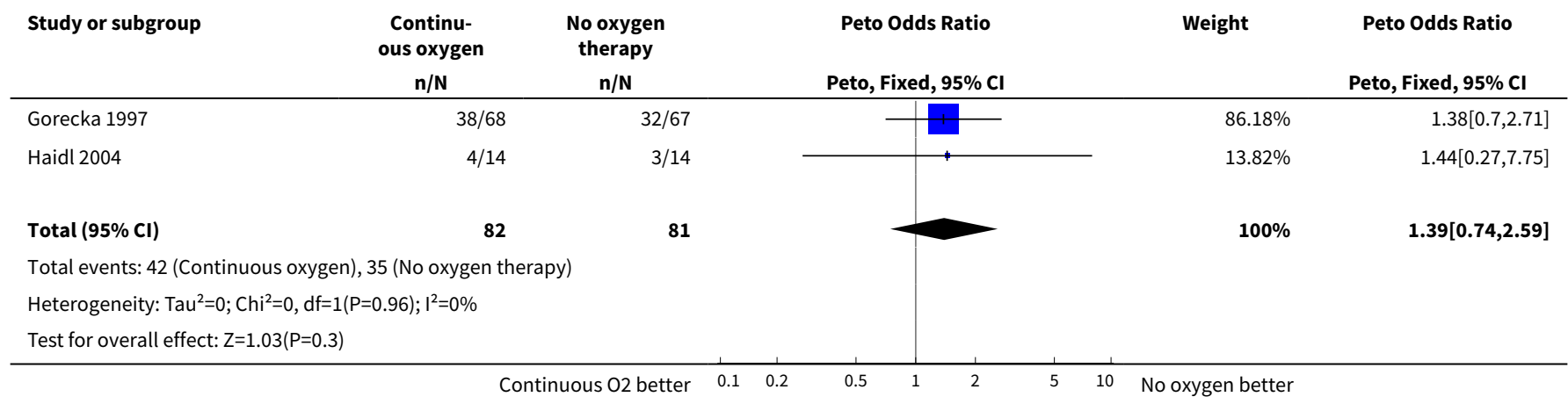

Analysis 4.2. Comparison 4 Long term oxygen therapy versus no oxygen therapy in mild to moderate hypoxaemia, Outcome 2 Mortality between oxygen $>15 \mathrm{hrs}$ per day and $<15 \mathrm{hrs}$ per day.

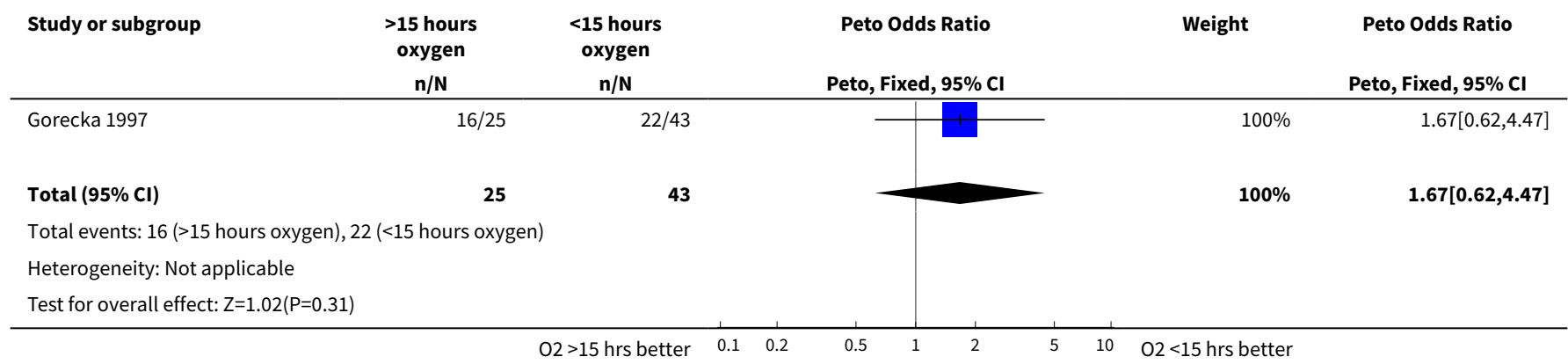

Analysis 4.3. Comparison 4 Long term oxygen therapy versus no oxygen therapy in mild to moderate hypoxaemia, Outcome 3 End exercise dyspnoea score.

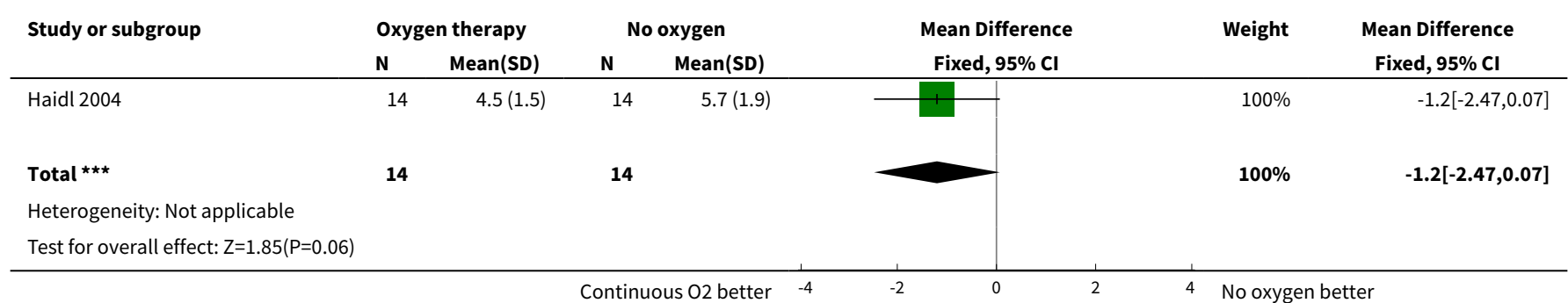

Analysis 4.4. Comparison 4 Long term oxygen therapy versus no oxygen therapy in mild to moderate hypoxaemia, Outcome 4 Endurance time.

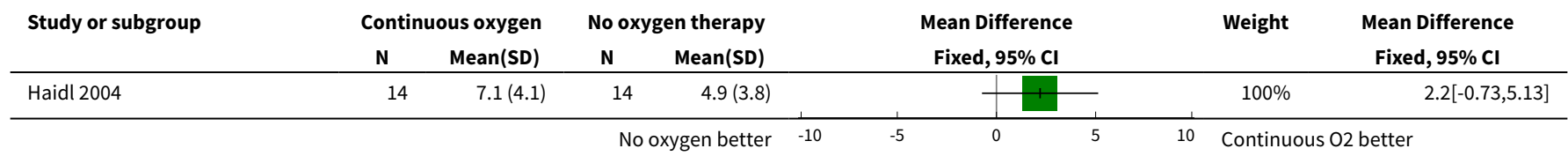




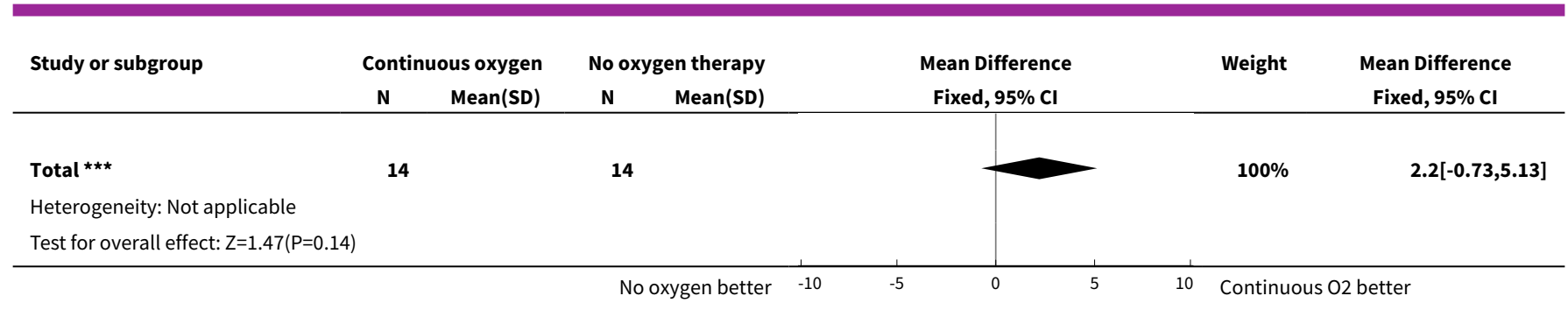

WHAT'S NEW

\begin{tabular}{lll}
\hline Date & Event & Description \\
\hline 23 July 2008 & Amended & Converted to new review format. \\
\hline
\end{tabular}

\section{HISTORY}

Protocol first published: Issue 1, 1998

Review first published: Issue 2, 2000

\begin{tabular}{lll}
\hline Date & Event & Description \\
\hline 7 June 2005 & $\begin{array}{l}\text { New citation required and conclusions } \\
\text { have changed }\end{array}$ & Substantive amendment \\
\hline
\end{tabular}

\section{CONTRIBUTIONS OF AUTHORS}

$\mathrm{AC}$ and $\mathrm{JC}$ initiated the study. $\mathrm{JM}, \mathrm{AC}$ and $\mathrm{JC}$ reviewed the trials.

$\mathrm{JC}$ was responsible for data entry and analysis. All reviewers participated in the discussion and interpretation of the results. JC and AJC wrote the paper. JC wrote the 2001 and the 2005 updates of the review.

\section{DECLARATIONS OF INTEREST}

None known.

\section{SOURCES OF SUPPORT}

\section{Internal sources}

- Australasian Cochrane Centre, Australia.

\section{External sources}

- No sources of support supplied

\section{INDEX TERMS}

\section{Medical Subject Headings (MeSH)}

*Home Care Services; *Oxygen Inhalation Therapy; Hypoxia [therapy]; Pulmonary Disease, Chronic Obstructive [ ${ }^{\star}$ therapy]; Randomized Controlled Trials as Topic; Self Care

\section{MeSH check words}

Humans 